Nutrient Dynamics and Retention in Land/Water Ecotones of Lowland, Temperate Lakes and Rivers.

(C) 1993 Kluwer Academic Publishers. Printed in Belgium.

\title{
Growth and nutrient uptake by two species of Elodea in experimental conditions and their role in nutrient accumulation in a macrophyte- dominated lake
}

\author{
Teresa Ozimek ${ }^{1}$, Ellen van Donk ${ }^{2}$ \& Ramesh D. Gulati ${ }^{3}$ \\ ${ }^{1}$ Department of Hydrobiology, Institute of Zoology, University of Warsaw, Nowy Swiat 67, 00-046 \\ Warsaw, Poland; ${ }^{2}$ Department of Nature Conservation, Section of Aquatic Ecology, Agricultural University \\ of Wageningen, P.O. Box 8080, 6700 DD Wageningen. The Netherlands; ${ }^{3}$ Limnological Institute, \\ Vijverhof Laboratory, Rijksstraatweg 6,3631 AC Nieuwersluis, The Netherlands
}

Key words: submerged macrophytes, phosphorus and nitrogen cycling, hypcrtrophic waters

\begin{abstract}
The capacity of Elodea nuttallii (Planch.) St. John and Elodea canadensis Michx. to remove nitrogen from water was evaluated in laboratory experiment. The growth rate of plants and their effect on the nitrogen level of hypertrophic Lake Zwemlust (the Netherlands) as well as on lake water enriched with nitrogen were investigated. The plants grew best in water enriched with up to $2 \mathrm{mg} \mathrm{NH}_{4}-\mathrm{N}^{-1}$ and $2 \mathrm{mg} \mathrm{NH} \mathrm{NH}_{4}-\mathrm{N}^{-1}$ plus $2 \mathrm{mg} \mathrm{NO}-\mathrm{N}^{-1}$. During a 14 day experiment, plants absorbed from $75 \%$ to $90 \%$ of nitrogen. Higher nitrogen concentration than $4 \mathrm{mg}^{-1}$ had a negative effect on growth of both species. Elodea nuttallii and E. canadensis prefer $\mathrm{NO}_{4}^{+}$over $\mathrm{NO}_{3}^{-}$when both ions were present in water in equal concentrations.
\end{abstract}

\section{Introduction}

Submerged macrophytes grow between the shoreline and open waters and they can intercept or modify material flows from land to the pelagial. Most of them are rooted and constitute a living link between sediments and the overlaying water. They build an ecotone - horizontaly between land and open water and verticaly between sediments and overlaying water. Submerged macrophytes can play a central role in nutrient cycling, especially in small, shallow lakes. They often accumulate large quantities of inorganic elements (Boyd, 1968; Boyd, 1971; Hutchinson, 1975) and can thus have major effects on phosphorus and nitrogen cycling if their biomass is high (Carpen- ter \& Lodge, 1986; Reddy et al., 1987). Submerged macrophytes, despite of their well developed root systems, absorb some mineral elements directly from the water, especially those with a large foliage surface area (Agami \& Waisel, 1986).

In small, shallow lakes dominated by submerged macrophytes, deficiences of some nutrients may occur (Boyd, 1971). This occurred in Zwemlust, a small (1.7 ha) lake in the Netherlands, after steps were taken to restore the lake by biomanipulation in 1987 (Van Donk et al., 1989). Before and during the biomanipulation, aquatic plants were absent. After biomanipulation they rapidly developed and occupied $70 \%$ of the lake bottom in summer 1988 and almost 100\% in summer 1989 (Ozimek et al., 1990). Elodea 
nuttallii (Planch.) St. John was the dominant species.

In summer 1988, when plants were abundant, nitrate and ammonia nitrogen concentrations declined to near detection level. Phosphorus concentration was high (about $1 \mathrm{mg} \mathrm{PO}_{4}-\mathrm{P}^{-1}$ ) and stable (Van Donk et al., 1989).

The goal of our research was to quantify the effect of E. nuttallii and E. canadensis Michx. on phosphorus and nitrogen concentrations in Lake Zwemlust, and to evaluate the ability of these plants to remove nitrogen and phosphorus from nutrient-rich waters. Elodea nuttallii and E.canadensis are common species not only in small, shallow lakes but they can also be dominant in the littoral of big lakes (Kuni, 1982; Ozimek, 1983). Their role in nitrogen and phosphorus cycling was studied in laboratory experiments.

\section{Material and methods}

Elodea nuttallii and E. canadensis were collected in September 1988 from Lake Zwemlust. The plants were washed under running tap water, taking care not to damage their tissues. The apical, portion $(\mathrm{ca} 20 \mathrm{~cm})$ of mother shoots were cut off and acclimatized for 3 days in the laboratory $\left(19^{\circ} \mathrm{C}\right.$; $16: 8$ dark:light; $30 \mathrm{~W} \mathrm{~m}^{-2}$ PAR) before the experiments. Several samples of each species were weighed, dried $\left(105{ }^{\circ} \mathrm{C}\right.$ for $\left.24 \mathrm{~h}\right)$ and reweighed, to measure fresh and dry weight, respectively.

The growth rate of E. nuttallii and E. canadensis was studied under different concentrations of nitrogen (Table 1). For each nitrogen concentration, three one-litre aquaria were used. Five shoots each of $E$. nuttallii and $E$. canadensis were separately cultivated in an aquarium for 14 days. Initial shoots were without lateral shoots and roots. The variables measured at the beginning and the end of experiments wcre: 1ength of shoots, fresh weight of each shoots and roots (E. nuttallii: experiments I-IV; E. canadensis: IA-IVA), total fresh weight of plants in each aquarium, concentrations of $\mathrm{NH}_{4}-\mathrm{N}, \mathrm{NO}_{3}-\mathrm{N}, \mathrm{PO}_{4}-\mathrm{P}$ in water (E. nuttallii: experiments I-VII; E. canadensis:
Table 1. Nitrogen concentration for the growth rate experiment with Elodea nuttallii and E. canadensis from Lake Zwemlust. Each experiments had three replicates.

\begin{tabular}{lll}
\hline Nitrogen concentration & \multicolumn{2}{l}{ Experiment number } \\
\cline { 2 - 3 } mg $1^{-1}$ & E. nuttallii & E. canadensis \\
\hline Water from Lake Zwemlust & I & I A \\
Water $+2 \mathrm{mg} \mathrm{NO}_{3}-\mathrm{N}$ & II & II A \\
Water $+2 \mathrm{mg} \mathrm{NH}_{4}-\mathrm{N}$ & III & III A \\
Water $+2 \mathrm{mg} \mathrm{NO}_{3}-\mathrm{N}+2 \mathrm{mg} \mathrm{NH}_{4}-\mathrm{N}$ & IV & IV A \\
Water $+5 \mathrm{mg} \mathrm{NO}_{3}-\mathrm{N}$ & V & V A \\
Water $+5 \mathrm{mg} \mathrm{NH}_{4}-\mathrm{N}$ & VI & VI A \\
Water $+5 \mathrm{mg} \mathrm{NO}_{3}-\mathrm{N}+5 \mathrm{mg} \mathrm{NH}_{4}-\mathrm{N}$ & VII & VII A \\
\hline
\end{tabular}

experiments IA-VIIA; Table 1). The average relative growth rate $(\overline{\mathrm{R}})$ was calculated using the following equation (Hunt, 1978):

$$
\bar{R}=\frac{\ln W_{2}-\ln W_{1}}{T_{2}-T_{1}}
$$

where $R$ is the average weight-specific growth rate (g d.w. $\mathrm{g}^{-1}$ d.w. day ${ }^{-1}$ ), and $W_{1}$ and $W_{2}$ are plant weights at time $T_{1}$ and time $T_{2}$, respectively, in days.

Preferential uptake of $\mathrm{NH}_{4}-\mathrm{N}$ or $\mathrm{NO}_{3}-\mathrm{N}$ by plants was measured in the laboratory. One-litre aquaria containing filtered water (Whatman $\mathrm{GF} / \mathrm{F}$ ) from Lake Zwemlust enriched with $2 \mathrm{mg} \mathrm{NH}{ }_{4}-\mathrm{N1}^{-1}$ and $2 \mathrm{mg} \mathrm{NO}_{3}-\mathrm{Nl}^{-1}$, or with $5 \mathrm{~mm} \mathrm{NH}_{4}-\mathrm{N}^{-1}$ and $5 \mathrm{mg} \mathrm{NO}_{3}-\mathrm{N}^{-1}$ were used. Five shoots of E. nuttallii or 5 shoots of E. canadensis were cultivated. The control aquaria were without plants. The concentration of $\mathrm{NH}_{4}-\mathrm{N}, \mathrm{NO}_{3}-\mathrm{N}$ were measured after $4,8,16,32$ and 64 hours. Three replicates were used for each exposure time.

$\mathrm{PO}_{4}-\mathrm{P}$ was determined according to Murphy \& Riley (1962), $\mathrm{NO}_{3}-\mathrm{N}$ according to Stainton et al. (1974), and $\mathrm{NH}_{4}-\mathrm{N}$ following Verdouv et al. (1977), using a Cerco automated analyzer.

\section{Results}

Growth and dry weight yield

Initial dry weight did not significantly differ. Length and dry weight of individual shoots of 
Table 2. Growth of individual shoot of Elodea nuttallii under different nitrogen treatments during 14-day laboratory experiments. Means $(n=15)$ with $95 \%$ confidence limits in parentheses.

\begin{tabular}{|c|c|c|c|c|c|c|}
\hline \multirow{2}{*}{$\begin{array}{l}\text { Experiment } \\
\text { no. (see } \\
\text { table 1) }\end{array}$} & \multicolumn{2}{|c|}{ Length $(\mathrm{cm})$} & \multicolumn{2}{|c|}{ Dry weigh (mg) } & \multirow{2}{*}{$\begin{array}{l}\text { Specific } \\
\text { growth } \\
\text { (mg d.w. } \\
\mathrm{mg}^{-1} \mathrm{~d} . \mathrm{w} . \\
\mathrm{day}^{-1} \text { ) }\end{array}$} & \multirow{2}{*}{$\begin{array}{l}\% \text { share } \\
\text { of roots } \\
\text { in final } \\
\text { d.w. }\end{array}$} \\
\hline & Initial & Final & Initial & Final & & \\
\hline I & $21.2(0.8)$ & $29.4(2.0)$ & $60(4)$ & $74(8)$ & 0.015 & 12.7 \\
\hline II & $24.0(1.3)$ & $38.4(3.6)$ & $76(10)$ & $128(16)$ & 0.037 & 4.3 \\
\hline III & $21.8(0.6)$ & $45.4(5.4)$ & $80(14)$ & $176(26)$ & 0.056 & 4.4 \\
\hline IV & $22.2(0.4)$ & $47.8(4.8)$ & $76(8)$ & $172(20)$ & 0.058 & 3.4 \\
\hline
\end{tabular}

E. nuttallii under different nitrogen treatments differed (Table 2). $\mathrm{NO}_{4}-\mathrm{N}$ enrichment in the bioassays had a greater effect on plant growth than $\mathrm{NO}_{3}-\mathrm{N}$. The plants grew best in water enriched with $2 \mathrm{mg} \mathrm{NH}_{4}-\mathrm{N}$ and with $2 \mathrm{mg} \mathrm{NH}_{4}-\mathrm{N}$ plus $2 \mathrm{mg} \mathrm{NO}_{3}-\mathrm{N}^{-1}$. Similar results were obtained for $E$. canadensis (Table 3 ). Final dry weight of plants in experiments I and III; I and IV and IA and IIA; IA and IVA significantly differed (Mann-Whitney U-test, $\mathrm{P}<0.01$ ).

The plants cultivated in non-enriched nitrogen water had the highest share of roots in their total biomass (Tables 2 and 3).

The relative growth rate of both Elodea species was from 2 to 4 times higher in the $\mathrm{N}$-enriched water than in the controls, and that of $E$. nuttallii was higher than that of $E$. canadensis in all experiments (Tables 2 and 3). This was true for the total biomass increments for both species (Figs 1 and 2). Higher nitrogen concentrations than $4 \mathrm{mg} 1^{-1}$ had negative effects on dry weight yield

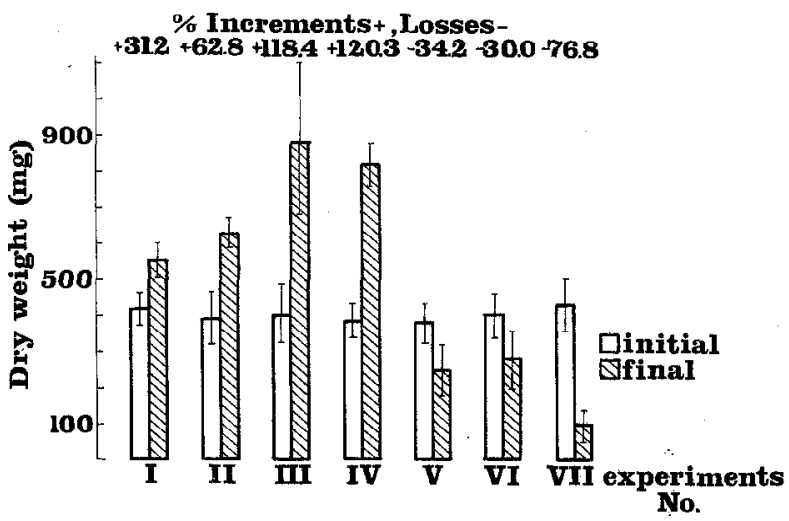

Fig. 1. Changes of dry weight of Elodea nuttallii under different nitrogen treatments (for codes see Table 1).

in both species. Plants grew and new lateral shoots were observed, but old shoots started to die. Increment was lower than loss, so the final dry weight was lower than the initial dry weight. At $10 \mathrm{mg} \mathrm{n} 1^{-1}$, loss of dry weight was ca $77 \%$ for E. nuttallii (Fig. 1) and ca $52 \%$ for E. canadensis (Fig. 2).

Table 3. Growth of individual shoot of Elodea canadensis under different nitrogen treatments during 14-day laboratory experiments. Means $(n=15)$ with $95 \%$ confidence limits in parentheses.

\begin{tabular}{|c|c|c|c|c|c|c|}
\hline \multirow{2}{*}{$\begin{array}{l}\text { Experiment } \\
\text { no. (see } \\
\text { table 1) }\end{array}$} & \multicolumn{2}{|c|}{ Length $(\mathrm{cm})$} & \multicolumn{2}{|c|}{ Dry weigh (mg) } & \multirow{2}{*}{$\begin{array}{l}\text { Specific } \\
\text { growth } \\
\text { (mg d.w. } \\
\mathrm{mg}^{-1} \text { d.w. } \\
\text { day }^{1} \text { ) }\end{array}$} & \multirow{2}{*}{$\begin{array}{l}\% \text { share } \\
\text { of ronts } \\
\text { in final } \\
\text { d.w. }\end{array}$} \\
\hline & Initial & Final & Initial & Final & & \\
\hline I A & $20.8(2.5)$ & $30.2(2.0)$ & $97(21.0)$ & $111(19)$ & 0.010 & 14.9 \\
\hline II A & $17.8(1.8)$ & $34.6(5.6)$ & $93(14.0)$ & $116(17)$ & 0.016 & 6.5 \\
\hline III A & $17.8(1.5)$ & $40.8(3.4)$ & $88(11.0)$ & $156(28)$ & 0.041 & 6.4 \\
\hline IV A & $18.1(2.4)$ & $39.6(4.4)$ & $85(11.8)$ & $146(28)$ & 0.039 & 5.3 \\
\hline
\end{tabular}




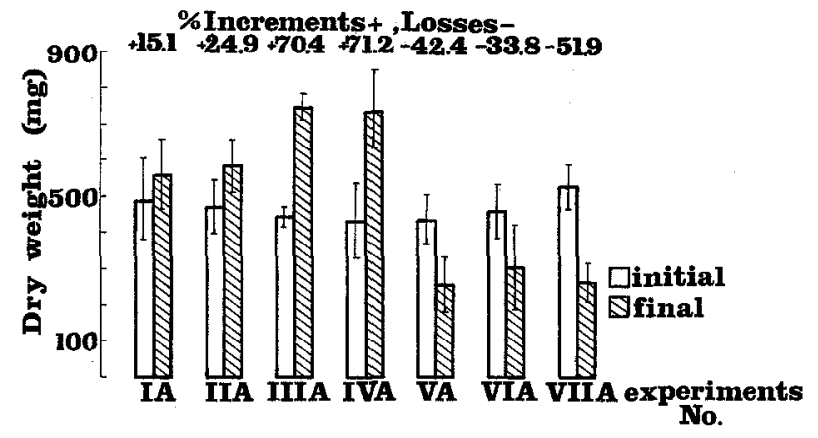

Fig. 2. Changes of dry weight of Elodea canadensis under different nitrogen treatments (for codes see Table 1).

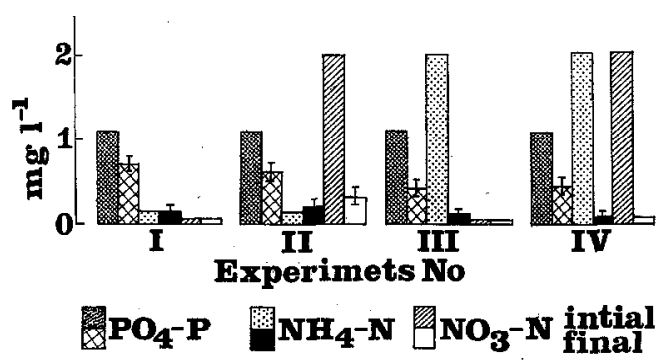

Fig. 3. Changes in the concentrations of $\mathrm{NH}_{4}-\mathrm{N}, \mathrm{NO}_{3}-\mathrm{N}$ and $\mathrm{PO}_{4}-\mathrm{P}$ in the medium after 14 days of cultivation of Elodea nuttallii (codes as in Table 1).

Elodea nuttallii and E. canadensis seemed to play a significant part in nitrogen cycling. During the 14 days of these experiments, plants absorbed about $50 \%$ of the phosphorus and from $75 \%$ to $90 \%$ of the nitrogen offered (Figs 3 and 4). Depending on nitrogen concentrations in water, $E$. nuttallii can utilize $0-9 \mathrm{mg} \mathrm{N} \mathrm{g}^{-1} \mathrm{~d}$.w. and E. canadensis $0-6.5 \mathrm{mg} \mathrm{g}^{-1} \mathrm{~d} . \mathrm{w}$. Their respective phosphorus demands are $1.3-1.6 \mathrm{mg} \mathrm{P} \mathrm{g}^{-1} \mathrm{~d}$.w. and 1.0-1.6 $\mathrm{mg} \mathrm{P} \mathrm{g}^{-1} \mathrm{~d}$.w.

\section{Preferential uptake of inorganic nitrogen}

Both species of Elodea prefer $\mathrm{NH}_{+4}$ to $\mathrm{NO}_{3}^{+}$if both ions are present in water at the same concentrations (Figs 5-8). In water enriched with $2 \mathrm{mg} \mathrm{NH}-\mathrm{N}$ and $2 \mathrm{mg} \mathrm{NO}-\mathrm{N}$ a $50 \%$ reduction of initial $\mathrm{NH}_{4}^{+}$concentration was noted after $8 \mathrm{~h}$ and $90 \%$ after $32 \mathrm{~h}$. The plants started to absorb $\mathrm{NO}_{3}-\mathrm{N}$ after $16 \mathrm{~h}$ and this absorption increased

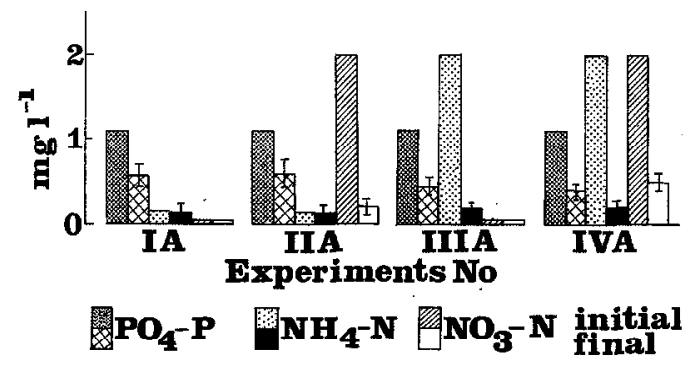

Fig. 4. Changes in the concentrations of $\mathrm{NH}_{4}-\mathrm{N}, \mathrm{NO}_{3}-\mathrm{N}$ and $\mathrm{PO}_{4}-\mathrm{P}$ in the medium after 14 days of cultivation of Elodea canadensis (codes as in Table 1).

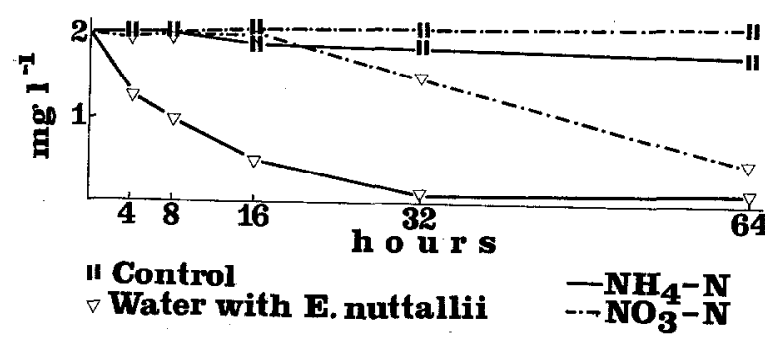

Fig. 5. Eflect of Elodea nuttallii on changes of nitrogen concentrations in water enriched up to $2 \mathrm{mg} \mathrm{NH}_{4}-\mathrm{N}^{-1}$ and $2 \mathrm{mg} \mathrm{NO} \mathrm{NO}^{-1}$.

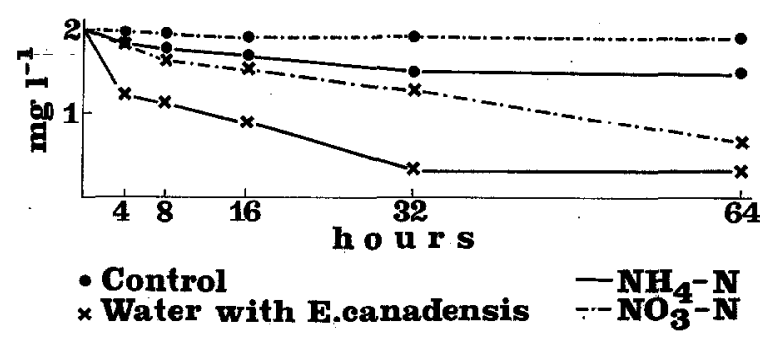

Fig. 6. Effect of Elodea canadensis on changes of nitrogen concentrations in water enriched up to $2 \mathrm{mg} \mathrm{NH}_{4}-\mathrm{N}^{-1}$ and $2 \mathrm{mg} \mathrm{NO}_{3}-\mathrm{N}^{-1}$.

after $32 \mathrm{~h}$ when $\mathrm{NH}_{4}$-IV levels dropped below detection level. After $64 \mathrm{~h} 75 \%$ of the added $\mathrm{NO}_{3}-\mathrm{N}$ was taken up by the plants (Figs 5 and 6).

In experiments in which $E$. nuttallii and $E$. $c a-$ nadensis were cultivated in water with addition of $5 \mathrm{mg} \mathrm{NH}-\mathrm{N}$ plus $5 \mathrm{mg} \mathrm{NO}-\mathrm{N}$ at the beginning, the plants absorbed only $\mathrm{NH}_{4}-\mathrm{N}$, but after $16 \mathrm{~h}$ the plants started to die and leach nitrogen (Figs 7 and 8). 


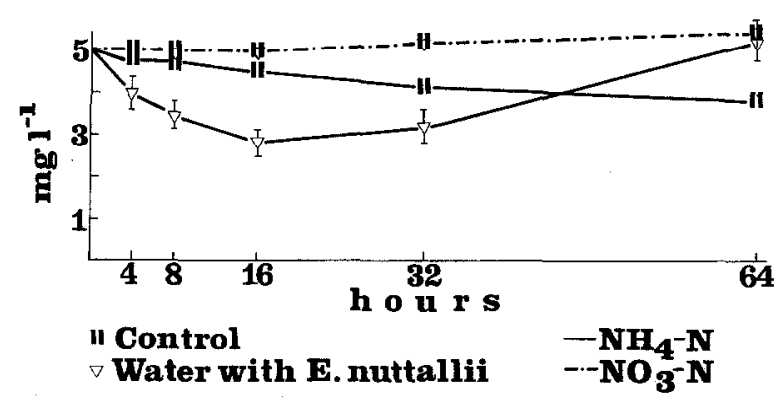

Fig. 7. Effect of Elodea nuttallii on changes of nitrogen concentrations in water enriched up to $5 \mathrm{mg} \mathrm{NH}_{4}-\mathrm{N1}^{-1}$ and $5 \mathrm{mg} \mathrm{NO}_{3}-\mathrm{N}^{-1}$.

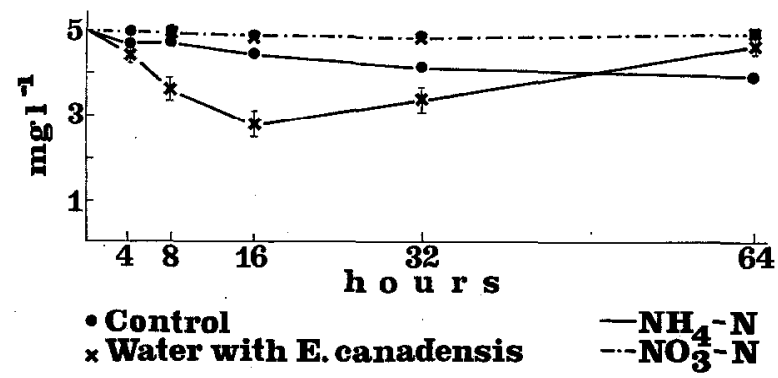

Fig. 8. Effect of Elodea canadensis on changes of nitrugen concentrations in water enriched up to $5 \mathrm{mg} \mathrm{NH}_{4}-\mathrm{N}^{-1}$ and $5 \mathrm{mg} \mathrm{NO}-\mathrm{N} \mathrm{I}^{-1}$.

\section{Discussion}

Elodea nuttallii and E. canadensis occurred in small amounts in Lake Zwemlust in 1987, the year the lake was biomanipulated (van Donk et al., 1989). The conditions for plant growth were favourable; Secchi-depth extended to the bottom, phosphorus concentration was about $1 \mathrm{mg} \mathrm{PO}_{4^{-}}$ $\mathrm{P}^{-1}$ and nitrogen concentration about $2 \mathrm{mg} \mathrm{l}^{-1}$, which was found optimal for both species in the bioassay experiments. Both Elodea spp. exhibited similar patterns of growth and nutrient uptake. Thus, what caused the dominance of $E$. nuttallii in 1988 and 1989, when $E$. canadensis occupied only about $3 \%$ of the lake bottom and thus had a much lower biomass than E. nuttallii (Ozimek et al., 1990). Kuni (1982) showed that E. nuttallii can grow slightly even in winter if the mean watcr temperature is higher than $4{ }^{\circ} \mathrm{C}$. The critical temperature for vegetative growth of this species lies between 8.2 and $12.0^{\circ} \mathrm{C}$ (Kuni, 1982), E. ca- nadensis needs higher temperatures for active growth. Therefore, E. nuttallii starts growing earlier than E. canadensis, and its growth rate is higher. In Lake Zwemlust, E. nuttallii started growing actively in April 1988. At this time phytoplankton was effectively controlled by zooplankton (Gulati, 1989; Van Donk et al., 1989), and therefore macrophyte competition for nutrients with phytoplankton was not important.

Elodea nuttallii can absorb and accumulate large quantities of nitrogen as shown in our laboratory experiments. This species was mainly responsible for the decrease of nitrogen concentration in I ake 7wemlust to below detection level.

Different forms of nitrogen, both organic and inorganic, can be utilized by aquatic plants: $\mathrm{NH}_{4}-\mathrm{N}$ and $\mathrm{NO}_{3}-\mathrm{N}$ being the preferable ones (Forsberg, 1975). Elodea nuttallii and E. canadensis can use both these ions but prefer $\mathrm{NH}_{4}-\mathrm{N}$. Similar results were reported for other species (Toetz, 1974; Reddy et al., 1987).

In the summer of 1988 and 1989 E. nuttallii and E. canadensis in Lake Zwemlust had long roots, growing from the tops of its shoots (Ozimek, unpubl.). In laboratory experiments this phenomenon was observed in plants cultivated using low nitrogen concentrations. Curtis \& Clark (1975) and our experimental results show that the root to shoot ratio may be a good indicator of a lack of nitrogen in the environment.

\section{Conclusion}

1. Elodea nuttallii and E. canadensis have the potential to remove nitrogen from hypertrophic waters.

2. Both species can grow in water in which the nitrogen concentration does not exceed $4 \mathrm{mg} \mathrm{l}^{-1}$.

3. Elodea canadensis can be more profitably used in removing nitrogen from water, because it is widely distributed in the world.

\section{Acknowledgements}

The first author thanks the Limnological Institute for providing funds for her travel to the Nether- 
lands and stay at Nieuwersluis for her study on Lake Zwemlust.

\section{References}

Agami, M. \& Y. Waisel, 1986. The ecophysiology of roots of submerged vascular plants. Physiol. Veg. 24: 607-624.

Boyd, C. E., 1968. Some aspects of aquatic plant ecology. Res. Fish. Res. 3: 114-129.

Boyd, C. E., 1971. The limnological role of aquatic macrophytes and their relationship to reservoir management. Res. Fish. Limnol. 8: 153-166.

Carpenter, S. R. \& D. M. Lodge, 1986. Effects of submerged macrophytes on ecosystem processes. Aquat. Bot. 26: $341-$ 370.

Curtis, O. F. \& D. G. Clark, 1975. An introduction to plant physiology. McGraw-Hill Book Company, N.Y., Toronto, Lond., $812 \mathrm{pp}$.

Forsberg, C., 1975. Nitrogen as a growth factor in fresh water. In: Conference on Nitrogen as a Water Pollutant, Copenhagen: 1-20.

Gulati, R. D., 1989. Structure and feeding activities of zooplankton community in Lake Zwemlust, in the two years after biomanipulation. Hydrobiol. Bull. 23: 35-48.

Hunt, R., 1978. Plant growth analysis. Studies in Biology No. 96. Edward Arnold Ltd., Lond.: 12-16.

Hutchinsøn, G. E., 1975. A treatise on limnology. IIr Limnological botany. John Wiley Sons, N.Y., Lond., Sydney, Toronto, $660 \mathrm{pp}$.

Kuni, H., 1982. The critical water temperature for the active growth of Elodea nuttallii (Planch.) St. John. Jap. J. Ecol. 32: $111-112$.

Murphy, J. \& J. P. Riley, 1962. A modified single solution method for determination of phosphate in natural waters. Analyt. chim. Acta. 26: 31-36.

Ozimek, T., 1983. Biotic structure and processes in the lake system of r. Jorka watershed (Masurian Lakeland, Poland). $\mathrm{X}$. Biomass and distribution of submerged macrophytes. Ekol. pol. 31: 781-792.

Ozimek, T., R. D. Gulati \& E. Van Donk, 1990. Can macrophytes be useful in biomanipulation of lakes? The Lake Zwemlust example. In R. D. Gulati, E. H. R. R. Lammens, M.-L. Meijer \& E. van Donk (eds), Biomanipulation - Tool for Water Management. Developments in Hydrobiology 61. Kluwer Academic Publishers, Dordrecht: 399-407. Reprinted from Hydrobiologia 200/201.

Reddy, K. R., J. C. Tucker \&. W. F. Debusk, 1987. The role of Egeria in removing nitrogen and phosphorus from nutrient enriched waters. J. Aquat. Plant. Manage. 25: 1419.

Stainton, M. P., M. J. Capel \& P. J. Armstrong, 1974. The chemical analysis of freshwater. Miscellaneous special publications no. 25. Research and Development Directorate Freshwater Institute, Winnipeg, Manitoba.

Toel, D. W., 1974. Uplake and translocation of ammonia by freshwater hydrophytes. Ecology. 55: 199-201.

Van Donk, E., R. D. Gulati \& M. P. Grimm, 1989. Food web manipulation in Lake Zwemlust: positive and negative effects during the first two years. Hydrobiol. Bull. 23: 1934.

Verdouv, H. C., J. A. Echteld \& E. M. J. Dekkers, 1977. Ammonia determination based on indophenol formation with sodium salicylate. Wat. Res. 12: 399-402. 